\title{
Potential benefit of trace element supplementation of sheep on a low level of nutrition
}

\author{
M.C. Cronjé, J.B.J. van Ryssen" and R.J. Coertze \\ Department of Animal \& Wildlife Sciences, University of Pretoria, Pretoria, 0002, South Africa
}

\begin{abstract}
A study was conducted to test whether supplementation of trace elements would have any beneficial effect on year-old ewes receiving a submaintenance level of nutrition. The ewes were fed a poor quality hay. The control group received no supplementation (Treatment 1$)$. A solution containing copper ( $\mathrm{Cu}, 5 \mathrm{mg} / \mathrm{d}$ ), selenium (Se, $1.6 \mathrm{mg} / \mathrm{d}$ ) and zinc (Zn, $48.2 \mathrm{mg} / \mathrm{d}$ ) was dosed twice a day to sheep in Treatment 2 while the ewes in Treatment 3 received a double dose of the three elements. Tissue analyses at the end of the 93-day experimental period suggested that the lambs in the control group suffered from a marginal Se deficiency, while the intake of the other elements seemed to be sufficient. Within treatments, weight changes varied tremendously. Therefore, even though differences were not significant, the unsupplemented control group lost weight, while the sheep in the other two treatments maintained their initial body weights during the study. Likewise, the control group tended to have a lower immune response against an injected foreign protein than the supplemented treatments, though differences were not significant. Plasma in the control group showed significantly higher activities of creatine phosphatase and aspartate transaminase than the supplemented groups. This suggested that the supplemented elements protected the body against tissue damage. Although it is traditionally considered that deficiencies in energy and protein, as first limiting nutrients with the highest priority in nutrition, should be overcome before any response to trace element supplementation could be expected, many of the micronutrients are involved in antioxidant activities in the body. Results from this study suggested that positive responses to micronutrient supplementation could be possible if the body is subjected to oxidative stress during submaintenance levels of energy and/or protein nutrition.
\end{abstract}

Keywords: Antioxidants, drought, submaintenance, copper, selenium, zinc

" Corresponding author. E-mail: jvryssen@up.ac.za

\section{Introduction}

The concept that a first limiting nutrient will determine the response to nutrient supplementation is well established in animal nutrition. Van Niekerk \& Jacobs (1985) demonstrated that protein was the first limiting nutrient above energy or phosphorus $(\mathrm{P})$ in cattle overwintering on low quality forage in a typical sourveld feeding situation in South Africa. Judson \& McFarlane (1998) pointed out that in the dry season, nitrogen and available energy intakes are often the primary nutrients, thus limiting responses to $\mathrm{P}$ supplementation when cattle are grazing dry pastures. Caple \& McDonald (1983) stated that compared with inadequate energy and protein nutrition, parasitism and inadequate shelter during inclement weather, trace element deficiencies are not important causes of inadequate reproduction performance or productivity in sheep in Australia. Similarly, White (1996) pointed out that animals might show a diminished or nil response to a mineral supplement if energy intake is also limiting, and Hunter et al. (1982) concluded that any possible growth response to selenium (Se) supplementation would be masked by a low energy intake. According to Saville (1981), in a drought feeding situation the provision of adequate energy in a ration usually takes care of vitamins and minerals with the exception of vitamin A and calcium (Ca). Therefore, it can be concluded that, in general, a response to the supplementation of other nutrients, especially the micronutrients, could not be expected if the deficiency of the first limiting nutrient(s) has not been alleviated.

However, Halliwell (1994) pointed out that the depletion of antioxidants due to malnutrition would weaken the potential of the body to combat oxidative stress due to free radicals and concluded that, in a state of poor nutrition, the body would be more susceptible to infections. Antioxidants in the body form natural defences against free radicals. A deficiency in antioxidants would allow the harmful effects of free radicals, such as reduced performance, reduced fertility, increased susceptibility to diseases and decreased immunity, 
to be manifested (Larsen, 1993; Nockels, 1996; Gengelbach et al., 1997; Forsberg \& Wang, 2004). Antioxidants include products containing micronutrients such as superoxide dismutase (SOD) that contains manganese $(\mathrm{Mn})$ (present in the mitochondria) or copper $(\mathrm{Cu}) /$ zinc $(\mathrm{Zn})$ (present in cytosol), Se-dependent glutathione peroxidase (GSH-Px), iron (Fe)-containing transferrin and vitamins such as vitamins $\mathrm{E}$ and $\mathrm{C}$ and carotene (Karlmark, 1993).

In situations where the level of feeding of animals is at or below maintenance, e.g. during the dry winters in the sour grassveld areas of South Africa or during protracted droughts, the body is likely to be deficient in some of these antioxidants. Therefore, despite the generally accepted first priority of the macronutrients, energy and protein, in nutrition, it is postulated that animals subjected to low levels of nutrition would benefit from an adequate supply of the micronutrients involved in antioxidant functions in the body. This study investigated the effect of the supplementation of Se, $\mathrm{Cu}$ and $\mathrm{Zn}$ to sheep subjected to a low level of nutrition.

\section{Materials and Methods}

Thirty eight SA Mutton Merino ewes (ca. one year of age) were obtained from a commercial farm and transferred to the experimental farm of the University of Pretoria. During a preliminary period of three months the ewes were fed a poor quality hay diet without any supplementation except for free access to salt $(\mathrm{NaCl})$. At the end of this period five ewes were selected randomly and slaughtered. Their livers were collected and processed to get an indication of the mineral nutritional status of the animals at the onset of the trial. The remaining 33 ewes (weighing $34.2 \pm 3.2 \mathrm{~kg}$ ) were blocked according to body weight and allocated randomly within blocks to three treatments to attain a similar mean body weight per group at the onset of the experimental period.

The treatments were:

Treatment 1 - Control receiving no supplement;

Treatment 2 - A trace mineral solution (Table 1) administered orally twice a day;

Treatment 3 - A double dose of the trace mineral solution received by Treatment 2, dosed twice daily. The mineral solution consisted of a mixture of $\mathrm{Se}, \mathrm{Cu}$ and $\mathrm{Zn}$ containing salts dissolved in water. It was administered orally with a dosing gun twice a day. Quantities administered are given in Table 1.

The sheep were kept individually in roofed pens, and received approximately $950 \mathrm{~g}$ of poor quality Digitaria eriantha hay per sheep per day. Wastage was too high to record hay intake accurately, though samples of the hay offered were kept for chemical analyses. The lambs had free access to salt (NaCl) and water. Water troughs were cleaned daily. At the onset of the trial all sheep were dosed with a broadspectrum anthelmintic and vaccinated according to the local management programme.

Table 1 Mineral solution and elements orally administered to each sheep daily according to treatment

\begin{tabular}{|c|c|c|c|c|c|}
\hline \multirow[b]{2}{*}{$\begin{array}{l}\text { Element } \\
\text { dosed }\end{array}$} & \multicolumn{2}{|c|}{ Mineral salt } & \multicolumn{3}{|c|}{ Quantity* per sheep per day } \\
\hline & Salt used & $\begin{array}{c}\text { Quantity } \\
\text { g/5 L H } \mathrm{H}_{2} \mathrm{O}\end{array}$ & $\begin{array}{c}\text { Treatment } 1 \\
\text { Control } \\
\end{array}$ & $\begin{array}{l}\text { Treatment } 2^{* *} \\
\quad / 20 \mathrm{~mL}\end{array}$ & $\begin{array}{l}\text { Treatment } 3^{* *} \\
\quad / 40 \mathrm{~mL}\end{array}$ \\
\hline Selenium & $\begin{array}{c}\mathrm{Na}_{2} \mathrm{SeO}_{3} \\
(45.7 \% \mathrm{Se})\end{array}$ & 0.88 & 0 & $1.6 \mathrm{mg}$ & $3.2 \mathrm{mg}$ \\
\hline Zinc & $\begin{array}{l}\mathrm{ZnSO}_{4} \cdot \mathrm{H}_{2} \mathrm{O} \\
(36.5 \% \mathrm{Zn})\end{array}$ & 33.0 & 0 & $48.2 \mathrm{mg}$ & $96.4 \mathrm{mg}$ \\
\hline Copper & $\begin{array}{c}\mathrm{CuSO}_{4} .5 \mathrm{H}_{2} \mathrm{O} \\
(25.4 \% \mathrm{Cu})\end{array}$ & 4.92 & 0 & $5 \mathrm{mg}$ & $10 \mathrm{mg}$ \\
\hline
\end{tabular}

*Sheep in Treatment 2 received $47 \mu \mathrm{g}$ Se/kg body weight and those in Treatment 3, $94 \mu \mathrm{g}$ Se/kg body weight

** Dosed twice a day

Animals were weighed in the morning prior to feeding, on day 0 (day before trial started) and on days 15, 41, 61, 81 and 90 of the trial. Throughout the trial blood was collected through venipuncture from the external jugular vein prior to feeding. Two $10 \mathrm{~mL}$ heparinised vacutainer tubes per sheep were used to collect blood for Se analyses in whole blood and plasma. This was done throughout the trial, but only the results of the first and last collections will be reported. On day 50, blood was collected for the determination 
of packed cell volume (PCV), which was determined within two hours after collection. On days 1, 45 and 90 blood was collected for the analysis of superoxide dismutase (SOD, EC 1.15.1.1) activity in serum, and on day 90 for the determination of creatine kinase (CK; EC 2.7.3.2) and aspartate transaminase (AST; EC 2.6.1.1) activities in serum. Whole blood, serum and plasma were stored at $-16{ }^{\circ} \mathrm{C}$ pending the respective assays.

After 90 days on the experimental diets, the lambs were slaughtered over a period of five days through electrocution, exsanguination and severance of the spinal cord, giving a mean duration of the trial of 93 days. The kidneys, livers and hearts were collected and a muscle sample of $c a .2 .5 \times 2.5$ was dissected from the Longissimus dorsi at the last rib area and cleared from fat and connective tissues. Fresh liver and wet carcass weights were taken immediately after slaughter. In the laboratory, the kidney cortices were dissected out and kept for analysis. Samples containing a minimal number of veins and arteries were collected at the same locations from each liver and pooled. After removal of the fat, the apex of the heart was collected. These tissues were dried at $60{ }^{\circ} \mathrm{C}$ for 48 hours, milled and stored for Se analysis.

This experiment was conducted with the approval and under supervision of the Ethical Committee for Animal Experimentation of the University of Pretoria, South Africa.

Selenium concentration was determined by hydride generation, using atomic absorption spectrophotometry (AOAC, 2000; method 4.8.15). A bovine liver sample (no. 1577b; $0.73 \pm 0.06 \mathrm{mg} \mathrm{Se} / \mathrm{kg}$ DM) from the National Institute of Standards and Technology (NIST, US Department of Commerce, Gaithersburg, MD) was used as Standard Reference Material (SRM) and included in each batch of analyses, to verify the accuracy of the Se assay. The Se concentrations in whole blood and plasma are expressed on a weight and not volume basis because of the difficulty to measure blood volume accurately. After wet acid digestion with a nitric-perchloric acid mixture, the $\mathrm{Ca}, \mathrm{Mn}, \mathrm{Cu}$, cobalt $(\mathrm{Co})$ and $\mathrm{Zn}$ concentrations were measured using atomic absorption spectrophotometry. Packed cell volume was measured using a microhaematocrit. Plasma AST and CK activities and erythrocyte haemoglobin concentration were measured, using the respective Boehringer Mannheim analytical kits (Boehringer Mannheim GmbH Diagnostica, West Germany). Superoxide dismutase was measured using the RANSOD-method developed by Randox Laboratories (Product SD 125). Activity is expressed as units per milligram of haemoglobin.

On day 75 of the trial the immune systems of the sheep were challenged with a foreign protein to measure antibody response. A $0.5 \mathrm{~mL}$ mixture of saline washed erythrocytes from a cow, made up with sterile phosphate buffered saline ( $\mathrm{pH} 7.4$ ) to give a haematocrit value of $30 \%$, were injected intravenously into the jugular vein of each sheep. Blood was collected on day 74 to be used as base value and 26 days later (day 90). Antibody titres were measured by means of passive haemagluttination (Nicholson et al., 1993).

An analysis of variance with the GLM model (SAS, 2001) was used to determine the significance between treatments. The level of significance was tested using the Fisher test (Samuels, 1989).

\section{Results and Discussion}

The hay contained (/kg DM): 3.8 g Ca, 34 mg Zn, 10.8 mg Cu, 202 mg Mn, 3.2 mg Co and 73 g Se. The mineral composition of the hay suggested that adequate levels of micro-elements were present in the diet (NRC, 1985; McDowell, 1997), except for Se where concentrations of between 100 and $200 \mu \mathrm{g} / \mathrm{kg}$ DM are considered as the adequate range for sheep (NRC, 1985). The sheep were reluctant to consume the hay and because of the high wastage and feed selection, these hay analyses would not give a true indication of the quantity of the elements consumed by the animals. The concentrations of trace elements in the liver of the pre-experimental slaughter group were (/kg DM): Cu, $218 \pm 81 \mathrm{mg}$; Mn, $9.4 \pm 1.1 \mathrm{mg}$; Co, $2.3 \pm 0.2 \mathrm{mg}$ and Se, $419 \pm 58 \mu \mathrm{g}$. These hepatic concentrations in the livers were within the ranges indicating adequate intakes of the elements (Puls, 1994), except for Se, according to ranges suggested by Puls (1994).

The body weights of the ewes are presented in Figure 1. All ewes appeared emaciated. Wide variations in weights and weight changes were observed even within treatments. Consequently, differences between treatments were not statistically significant, though the unsupplemented group (Treatment 1) showed a weight loss throughout the trial while the two supplemented groups showed slight positive weight gains. Initial and final weights as well as weight changes are presented in Table 2. The lack of weight gain suggested that these yearling lambs actually experienced a negative growth. 


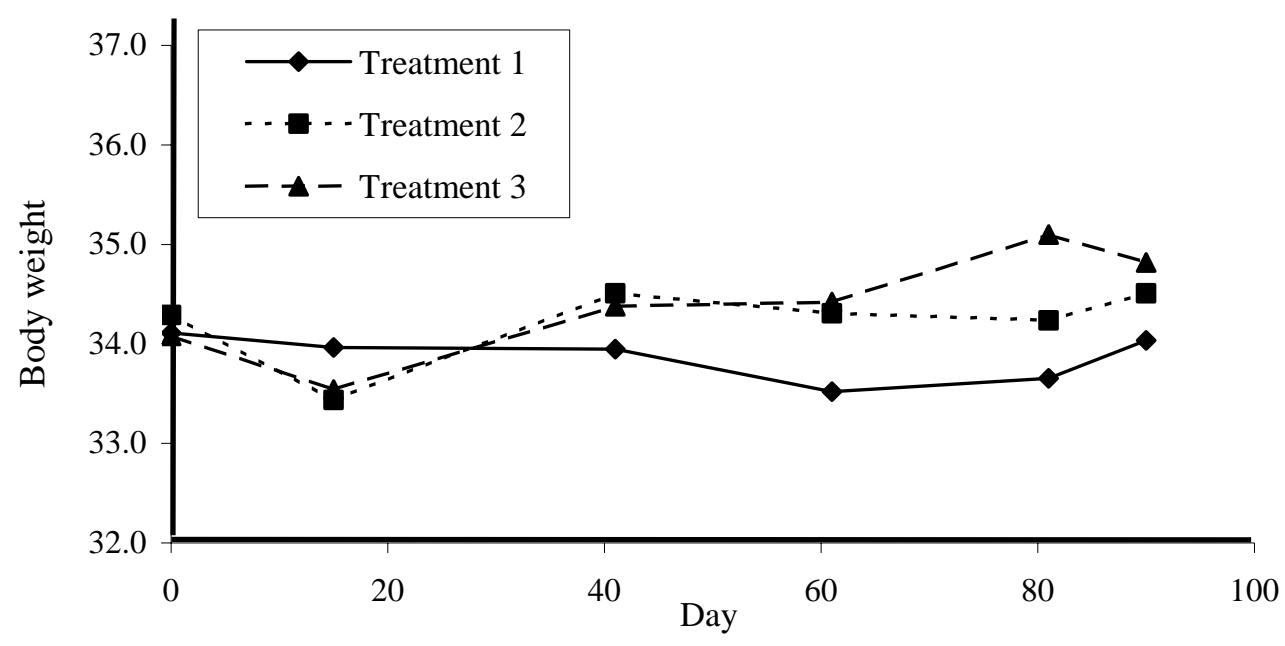

Figure 1 Body weights of the yearling lambs during the experimental period. Treatment 1 - control; Treatment 2 - trace element supplementation; Treatment 3 - trace element supplementation x 2

Table 2 Initial and final weights, weight changes and weight of liver as percentage of carcass weight of yearling lambs kept on a low level of nutrition with or without supplemental copper, zinc and selenium

\begin{tabular}{lcccc}
\hline & $\begin{array}{l}\text { Treatment } 1 \\
\text { Control }\end{array}$ & $\begin{array}{l}\text { Treatment 2 } \\
\text { Supplementation }\end{array}$ & $\begin{array}{c}\text { Treatment 3 } \\
\text { Supplementation X 2 }\end{array}$ & s.e.m. \\
\hline Initial weight & 34.1 & 34.3 & 34.1 & 3.1 \\
Final weight & 34.0 & 34.5 & 34.8 & 2.9 \\
Weight changes & -0.1 & 0.2 & 0.7 & - \\
Liver as \% carcass* & 3.4 & 3.1 & 3.4 & 0.3 \\
\hline
\end{tabular}

* Fresh liver weight as \% of hot carcass weight

Within rows differences were not significant $(\mathrm{P}>0.05)$

s.e.m. - standard error of the mean

Table 3 Mean selenium (Se) and copper (Cu) concentrations in tissues and blood at the end of the trial in yearling lambs kept on a low level of nutrition with or without supplemental copper, zinc and selenium

\begin{tabular}{|c|c|c|c|c|}
\hline \multirow[b]{2}{*}{ Tissues } & \multicolumn{4}{|c|}{ Treatments* } \\
\hline & $\begin{array}{l}\text { Treatment } 1 \\
\text { Control }\end{array}$ & $\begin{array}{c}\text { Treatment } 2 \\
\text { Supplementation }\end{array}$ & $\begin{array}{c}\text { Treatment } 3 \\
\text { Supplementation X } 2\end{array}$ & s.e.m. \\
\hline \multicolumn{5}{|l|}{ Liver: } \\
\hline Se $(\mu g / k g$ DM) & $165^{\mathrm{a}}$ & $10873^{b}$ & $27919^{c}$ & 4919 \\
\hline $\mathrm{Cu}(\mathrm{mg} / \mathrm{kg} \mathrm{DM})$ & $251^{b}$ & 316 & $425^{d}$ & 124 \\
\hline Mn (mg/kg DM) & 14.7 & 15.0 & 13.7 & 2.2 \\
\hline Heart Se ( $\mu g / k g ~ D M)$ & $113^{\mathrm{a}}$ & $1413^{b}$ & $1699^{c}$ & 90 \\
\hline L. dorsi Se $(\mu \mathrm{g} / \mathrm{kg} \mathrm{DM})$ & $43^{\mathrm{a}}$ & $427^{b}$ & $501^{\mathrm{d}}$ & 61 \\
\hline Kidney cortex Se ( $\mu \mathrm{g} / \mathrm{kg}$ DM) & $3521^{a}$ & $6933^{b}$ & $7516^{\mathrm{b}}$ & 1517 \\
\hline Plasma Se $(\mu \mathrm{g} / \mathrm{kg})$ & $14^{\mathrm{a}}$ & $172^{\mathrm{b}}$ & $242^{c}$ & 22 \\
\hline Whole blood Se ( $\mu \mathrm{g} / \mathrm{kg})$ & $26^{\mathrm{a}}$ & $337^{\mathrm{b}}$ & $435^{c}$ & 33 \\
\hline
\end{tabular}

\footnotetext{
* Within rows, means with different superscripts b-d differ significantly at $\mathrm{P}<0.05$

* Within rows, means with different superscripts a-b, b-c and a-c differ significantly at $\mathrm{P}<0.01$

s.e.m. - standard error of the mean
} 
Mean Se concentrations in tissues and blood at the end of the trial, as well as the $\mathrm{Cu}$ and $\mathrm{Mn}$ concentrations in the liver, are presented in Table 3. The Se concentrations in all the tissue and fluid samples differed significantly between treatments except for Se in the kidney cortices of the supplemented groups. The hepatic $\mathrm{Cu}$ concentrations in Treatments 1 and 3 differed $(\mathrm{P}<0.05)$, but differences in hepatic $\mathrm{Mn}$ concentrations were not significant. When trying to explain the high concentrations of Se in the livers of the supplemented sheep, it was realised that a mistake had been made in determining the Se dosage of the ewes. Instead of 0.16 or $0.32 \mathrm{mg}$ Se/sheep/day, the ewes received 10 times more Se. This amounted to doses approaching toxic levels. However, no toxic symptoms were observed and these high levels did not seem to have a significant influence on the interpretation of the results and the testing of the hypothesis of the study. Using the data of Echevarria et al. (1988) who fed 0, 3, 6 and $9 \mathrm{mg} \mathrm{Se} / \mathrm{kg}$ DM to sheep, to calculate Se and DM intake per kg body weight in the present study, it was estimated that the ewes in the present study received approximately 2.5 and $4 \mathrm{mg}$ Se/kg DM in Treatments 2 and 3, respectively, from the supplement. This is above the maximum tolerable level of $2 \mathrm{mg} / \mathrm{kg}$ DM suggested by the NRC (1985).

Mean Se concentration in the livers of the pre-experimental slaughter group at the onset of the trial was $419 \mu \mathrm{g} / \mathrm{kg}$. At the end of the trial the liver Se concentration of the unsupplemented group (Treatment 1) was $165 \mu \mathrm{g} / \mathrm{kg}$ DM. Puls (1994) suggested a range of ca. 380 - $750 \mu \mathrm{g}$ Se/kg liver DM (converted to DM basis) as indication of a marginal Se deficiency in sheep. McDowell (1997) recommended a concentration of $<250 \mu \mathrm{g}$ Se /kg DM as deficient while Underwood \& Suttle (1999) suggested a marginal band of ca. 60 $107 \mu \mathrm{g} \mathrm{Se} / \mathrm{kg}$ DM (converted to DM basis) which corresponds with the deficient range reported by New Zealand workers (Grace \& Clark, 1991).

Mean Se concentration in the whole blood at the onset of the present trial was $56 \mu \mathrm{g} / \mathrm{kg}$. In the control group not receiving any supplemental Se, the Se concentrations in both the plasma and blood decreased as the experiment progressed and reached concentrations of $14 \mu \mathrm{g} / \mathrm{kg}$ and $26 \mu \mathrm{g} / \mathrm{kg}$, respectively. These values were higher than the marginal bands for Se deprivation in sheep proposed by Underwood \& Suttle (1999), viz. in serum ca. 8 - $10 \mu \mathrm{g} / \mathrm{L}$ and in blood $c a .12$ and $20 \mu \mathrm{g} / \mathrm{L}$, but corresponded with the ranges of 6 - 30 $\mu \mathrm{g} / \mathrm{L}$ in serum and 3 - $50 \mu \mathrm{g} / \mathrm{L}$ in whole blood which Puls (1994) considered as indicative of a Se deficiency.

Table 4 Mean creatine phosphokinase (CK), aspartate transaminase (AST) and Cu-Zn superoxide dismutase (SOD) activities, packed cell volume (PCV) and antibody activity at the end of the trial in yearling lambs kept on a low level of nutrition with or without supplemental copper, zinc and selenium

\begin{tabular}{lcccc}
\hline & $\begin{array}{c}\text { Treatment } 1 \\
\text { Control }\end{array}$ & $\begin{array}{c}\text { Treatment 2 } \\
\text { Supplementation }\end{array}$ & $\begin{array}{c}\text { Treatment 3 } \\
\text { Supplementation X 2 }\end{array}$ & s.e.m. \\
\hline CK $(\mu / \mathrm{L})$ & $87^{\mathrm{a}}$ & $40^{\mathrm{b}}$ & $35^{\mathrm{b}}$ & 35 \\
AST $(\mu / \mathrm{L})$ & $96^{\mathrm{a}}$ & $48^{\mathrm{b}}$ & $45.1^{\mathrm{b}}$ & 43 \\
SOD $(\mathrm{U} / \mathrm{mg} \mathrm{Hb})^{* *}$ & 57.7 & 46.3 & 64.1 & 17.6 \\
PCV $(\%)$ & 32.9 & 34.4 & 34.2 & 5.3 \\
Antibody titres & 0.30 & 1.04 & 1.06 & 1.04 \\
\hline
\end{tabular}

\footnotetext{
$\mathrm{Hb}$ - haemoglobin; s.e.m. - standard error of the mean

* Within rows, means with superscripts a-b differ significantly at $\mathrm{P}<0.01$

** SOD means between treatments of blood collected on Days 0 and 45 did not differ $(\mathrm{P}>0.05)$ from those on Day 90, and are not presented
}

The enzyme activities, CK and AST, in the two supplemented groups were lower $(\mathrm{P}<0.05)$ than in the unsupplemented group (Table 4). Although no clinical symptoms of any deficiency were observed, elevated activities of these enzymes in plasma of animals indicate membrane destruction, with cell enzymes leaking into the circulation (Nockels, 1996). An elevated CK activity indicates mainly muscle cell damage and elevated AST activity mainly cell damage in the liver and internal organs (Schmidt \& Schmidt, 1967). Elevated activities of these enzymes are typically recorded when animals are suffering from a subclinical Se deficiency (Oh et al., 1976; Whanger et al., 1978). Supplementation of the three trace elements in the present study reduced $(\mathrm{P}<0.05)$ these enzyme activities in blood, thus protecting the body against tissue damage. 
The amounts of $\mathrm{Zn}$ and $\mathrm{Cu}$ dosed were above the requirements of sheep, but not close to toxic ranges (NRC, 1985), despite adequate concentrations in the hay. In all three treatments the liver Cu concentrations were within the range indicating an adequate intake. The liver $\mathrm{Cu}$ concentration in Treatment 3 was higher ( $\mathrm{P}$ $<0.05$ ) than in Treatment 1, but not close to a toxic level of $>600 \mathrm{mg} / \mathrm{kg} \mathrm{DM}$ (NRC, 1985; McDowell, 1997). Likewise, the SOD activity in the serum, which is related to the $\mathrm{Zn}$ and $\mathrm{Cu}$ status of the animal (Halliwell, 1994), did not differ significantly between treatments. It can be concluded that the sheep were not deficient in $\mathrm{Cu}$ and $\mathrm{Zn}$, and the supplementation of these elements probably would not have been a contributing factor to any response to the trace mineral supplementation in this study. It could therefore be concluded that the ewes suffered from a marginal Se deficiency and that the Se supplementation rectified this deficiency.

Hepatic Mn concentrations were within the range indicating an adequate Mn intake (Puls, 1994). The PCV concentrations did not differ between treatments, suggesting that the Fe intake was sufficient. At a dietary Se concentration of $10 \mathrm{mg} / \mathrm{kg}$ DM, Jenkins \& Hidiroglou (1986) observed a decrease in PCV in calves. They reported other studies that claimed that selenosis causes anaemia in animals. Echevarria et al. (1988) reported similar results where Se intakes were high, usually well above $5 \mathrm{mg} / \mathrm{kg} \mathrm{DM}$.

Although the mean antibody titres tended to be higher in the treated than in the untreated control in the present study, variations within treatments were high and differences between treatments were not significant (Table 4). In retrospect, it is unfortunate that more tests on immunity responses were not conducted in this study. This was restricted by the already large number of blood samples that was collected during the study.

Extrapolating from the results on drench feeding of calves by Jenkins \& Hidiroglou (1986), it seems possible that the dosing of the ewes in the present study with the experimental dose containing copper sulphate might have caused the closure of the oesophageal groove of the sheep. Thus would have allowed the micro-elements to enter the lower digestive tract without the interference of the microorganisms in the rumen and would result in a high absorption of these elements.

Since the year-old ewes did not put on weight over the experimental period of 90 days, it could be concluded that they were in a negative state of nutrition. This would be the result of a low dry matter and thus low energy and protein intakes, which would usually be the first limiting nutrients to the animals (Judson \& McFarlane, 1998). Whether other nutrients would be deficient, especially the micronutrients, would be largely coincidental. In the present study the ewes received sufficient $\mathrm{Cu}$ and $\mathrm{Zn}$, but were marginally deficient in Se. Rate of metabolism in the body would be low in animals under a submaintenance level of nutrition, which would limit the formation of metabolic end-products. However, low feed intakes could also result in an inadequate intake of some of the antioxidants, which could render the body vulnerable to an onslaught of pathogens and infection.

No toxic symptoms due to the high intake of Se were recorded. In fact, Se supplementation as ca. 4 $\mathrm{mg} / \mathrm{kg}$ in the diet was still beneficial in overcoming symptoms of tissue catabolism assumed to be due to a Se deficiency. However, it could be speculated that the decrease in weight of both treatment groups during the first two weeks could be the result of the high levels of Se application. At a supplemental level of $1 \mathrm{mg}$ Se (as selenite)/kg, Larsen et al. (1988) recorded a reduced immune response compared to lower levels of Se supplementation. They concluded that this could indicate the onset of cytotoxicity at $1 \mathrm{mg} \mathrm{Se} / \mathrm{kg}$, in which selenite started to act as a pro-oxidant. In the present study where selenite intakes were substantially higher than in Larsen's study, no evidence of a harmful effect attributable to selenite acting as a pro-oxidant was recorded. In fact, in all parameters measured, the highest dose of Se showed similar or even slightly better responses than the lower, though still probably toxic dose of Se. Both supplemental levels appeared to have been effective and beneficial in overcoming the Se deficiency in the sheep.

\section{Acknowledgements}

This material is based upon research supported by the South African National Research Foundation under grant number 2046855.

\section{References}

AOAC, 2000. Association of official analytical chemists. Official methods of analysis. $17^{\text {th }}$ ed. A.O.A.C. Arlington, Virginia, USA. 
Caple, I.W. \& McDonald, J.W., 1983. Trace mineral nutrition. In: Proc. No. 67 of the Postgraduate School, University of Sydney, Australia.

Echevarria, M.G., Henry, P.R., Ammerman, C.B. \& Rao, P.V., 1988. Effects of time and dietary selenium concentration as sodium selenite on tissue selenium uptake by sheep. J. Anim. Sci. 66, 2299-2305.

Forsberg, N.E. \& Wang, Y., 2004. Immunity, stress and nutritional support of immune function in stressed livestock. Pacific Northwest Animal Nutrition Conference, 5-7 October 2004, Seattle, Washington State, USA.

Gengelbach, G.P., Ward, J.D., Spears, J.W. \& Brown, T.T., 1997. Effects of copper deficiency and copper deficiency coupled with high iron or molybdenum on phagocytic cell function and response of calves to a respiratory disease challenge. J. Anim. Sci. 75, 1112-1118.

Grace, N.D. \& Clark, R.G., 1991. Trace element requirements, diagnosis and prevention of deficiencies in sheep and cattle. In: Physiological Aspects of Digestion and Metabolism in Ruminants. Eds Tsuda, T., Sasaki, Y. \& Kawashima, R., Academic Press, NY. pp. 321-346.

Halliwell, B., 1994. Free radicals and antioxidants: A personal view. Nutr. Rev. 52 (8), 253-265.

Hunter, R.A., Peter, D.W., Quin, M.P. \& Siebert, B.D., 1982. Intake of selenium and other nutrients in relation to selenium status and productivity of grazing sheep. Aust. J. Agric. Res. 33, 637-647.

Jansen van Rensburg, C., 2000. Die effek van organiese en anorganiese selenium op die immuunsisteem van skape. M.Sc. Agric. thesis, University of Pretoria, South Africa.

Jenkins K.J. \& Hidiroglou, M., 1986. Tolerance of the preruminant calf for selenium in milk replacer. J. Dairy Sci. 69, 1865-1870.

Judson, G.J. \& McFarlane, J.D., 1998. Mineral disorders in grazing livestock and the usefulness of soil and plant analysis in the assessment of these disorders. Aust. J. Exp. Agric. 38, 707-723.

Karlmark, B., 1993. Relation of selenium to other antioxidants, with special reference to free radicals. Norw. J. Agric. Sci., Suppl. 11, 11-20.

Larsen, H.J.S., 1993. Relation between selenium and immunity. Norw. J. Agric. Sci., Suppl. 11, 105-119.

Larsen, H.J., Øvernes, G. \& Moksnes, K., 1988. Effect of selenium on sheep lymphocytes response to mitogens. Res. Vet. Sci. 45, 11-15.

McDowell, L.R, 1997. Minerals for grazing ruminants in the tropical regions. $3^{\text {rd }}$ ed. Univ. Florida Coop. Extensive Services, Gainsville, Florida, USA.

Nicholson, J.W.G., Bush, R.S. \& Allen, J.G., 1993. Antibody responses of growing beef cattle fed silage diets with and without selenium supplementation. Can. J. Anim. Sci. 73, 355-365.

Nockels, C.F., 1996. Antioxidants improve cattle immunity following stress. Anim. Feed Sci. Technol. 62, 59-68.

NRC, 1985. Nutrient requirements of sheep. $6^{\text {th }}$ ed. National Academy of Sciences, National Research Council, Washington, D.C., USA.

Oh, S-H., Pope, A.L. \& Hoekstra, W.G., 1976. Dietary selenium requirements of sheep fed a practical-type diet as assessed by tissue glutathione peroxidase and other criteria. J. Anim. Sci. 42, 984-992.

Puls, R., 1994. Mineral Levels in Animal Health. Diagnostic Data. ${ }^{\text {nd }}$ ed. Sherpa Int, Canada.

Samuels, M.L., 1989. Statistics for the Life Sciences. Collier MacMillan Publishers, London.

SAS, 2001. Statistical Analysis Systems user's guide. Statistics V 6. SAS Institute Inc. Cary, N.C., USA

Saville, D.G., 1981. Management and feeding of grazing animals during drought. Ch 18 In: Grazing animals. Ed. Morley, F.H.W., World Animal Science, B1. Elsevier Scientific Publishing Co, Amsterdam. pp. 335-348.

Schmidt, E. \& Schmidt, F.W., 1967. Guide to Practical Enzyme Diagnosis. Published by C.F. Boehringer \& Soehne GmnH, Mannheim, Germany.

Underwood, E.J. \& Suttle, N.F., 1999. The mineral nutrition of livestock. $3^{\text {rd }}$ ed. CABI Publ., Oxon, UK.

Van Niekerk, B.D.H. \& Jacobs, G.A., 1985. Protein, energy and phosphorus supplementation of cattle fed low-quality forage. S. Afr. J. Anim. Sci. 15, 133-136.

Whanger, P.D., Weswig, P.H., Schmitz, J.A. \& Oldfield, J.E., 1978. Effects of various methods of selenium administration on white muscle disease, glutathione peroxidase and plasma enzyme activities in sheep. J. Anim. Sci. 47, 1157-1166.

White, C.L., 1996. Understanding the mineral requirements of sheep. In: Detection and Treatment of Mineral Nutrition Problems in Grazing Animals. Eds. Masters, D.G. \& White, C.L., Australian Centre for International Agricultural Research, Canberra. pp. 16-28. 